\title{
RESEARCH
}

Open Access

\section{Deforestation and fragmentation trends of seasonal dry tropical forest in Ecuador: impact on conservation}

\author{
Carlos A. Rivas ${ }^{1,2^{*}}$, José Guerrero-Casado ${ }^{3,4}$ and Rafael M. Navarro-Cerillo ${ }^{2}$
}

\begin{abstract}
Background: Fragmentation and deforestation are one of the greatest threats to forests, and these processes are of even more concern in the tropics, where the seasonal dry forest is possibly one of the most threatened ecosystems with the least remaining surface area.

Methods: The deforestation and fragmentation patterns that had occurred in Ecuadorian seasonal dry forests between 1990 and 2018 were verified, while geographic information systems and land cover shapes provided by the Ecuadorian Ministry of the Environment were employed to classify and evaluate three types of seasonal dry forests: deciduous, semi-deciduous, and transition. The study area was tessellated into $10 \mathrm{~km}^{2}$ hexagons, in which six fragmentation parameters were measured: number of patches, mean patch size, median patch size, total edge, edge density and reticular fragmentation index (RFI). The RFI was also measured both outside and inside protected natural areas (unprotected, national protected areas and protected forest). Moreover, the areas with the best and worst conservation status, connectivity and risk of disappearance values were identified by means of a Getis-Ord Gi* statistical analysis.
\end{abstract}

Results: The deforestation of seasonal dry forests affected $27.04 \%$ of the original surface area still remaining in 1990, with an annual deforestation rate of $-1.12 \%$ between 1990 and 2018 . The RFI has increased by $11.61 \%$ as a result of the fact that small fragments of forest have tended to disappear, while the large fragments have been fragmented into smaller ones. The semi-deciduous forest had the highest levels of fragmentation in 2018. The three categories of protection had significantly different levels of fragmentation, with lower RFI values in national protected areas and greater values in protected forests.

Conclusions: The seasonal dry forest is fragmenting, deforesting and disappearing in some areas. An increased protection and conservation of the Ecuadorian seasonal dry forest is, therefore, necessary owing to the fact that not all protection measures have been effective.

Keywords: Deciduous forest, Semi-deciduous forest, Remnant forest, Patch isolation, Habitat loss, Protected areas

\footnotetext{
* Correspondence: carlosrivascobo@gmail.com

${ }^{1}$ Instituto de Ciencias Básicas, Universidad Técnica de Manabí, Portoviejo,

Manabí, Ecuador

${ }^{2}$ Department of Forest Engineering, Laboratory of Dendrochronology,

Silviculture and Global Change - DendrodatLab - ERSAF, University of

Cordoba, Campus de Rabanales, Crta. IV, km. 396, E-14071 Cordoba, Spain

Full list of author information is available at the end of the article
}

\section{Springer Open}

(c) The Author(s). 2021 Open Access This article is licensed under a Creative Commons Attribution 4.0 International License, which permits use, sharing, adaptation, distribution and reproduction in any medium or format, as long as you give appropriate credit to the original author(s) and the source, provide a link to the Creative Commons licence, and indicate if changes were made. The images or other third party material in this article are included in the article's Creative Commons licence, unless indicated otherwise in a credit line to the material. If material is not included in the article's Creative Commons licence and your intended use is not permitted by statutory regulation or exceeds the permitted use, you will need to obtain permission directly from the copyright holder. To view a copy of this licence, visit http://creativecommons.org/licenses/by/4.0/. 


\section{Introduction}

The term 'forest fragmentation' refers to the spatial configuration and amount of treed-vegetation (Hermosilla et al. 2018), a landscape-level process during which anthropogenic factors progressively subdivide forest tracts into (initially, but not necessarily ultimately) smaller, geometrically more complex and more isolated patches as a result of natural processes and land use activities (McGarigal and Marks 1995; Chakraborty et al. 2017). This concept can refer to the entire process of forest loss and isolation or, more specifically, to changes in the spatial configuration of remnants of forest that are the result of deforestation (Fahrig 2003; Kupfer 2006). The fragmentation process involves changes in the composition, structure and function of the landscape, and occurs on a mosaic background of natural patches created by changing landforms and natural disturbances (McGarigal and Marks 1995; Asbjornsen et al. 2004).

At the landscape level, the most common effect of fragmentation is the formation of new edges or the modification of existing ones, which play a fundamental role in the structure and functioning of ecosystems (Forman and Godron 1989; Asbjornsen et al. 2004). These changes can alter ecological functions related to biodiversity, the nutrient cycle and the hydrological cycle, and may even affect the microclimate of the area (Asbjornsen et al. 2004; Taubert et al. 2018).

The increase in forest fragmentation is one of the main threats to natural tree populations in the tropics around the world (Trejo and Dirzo 2000; Fuchs et al. 2003), where large areas of forests have been transformed into pastures and crops, thus creating a mosaic of agricultural areas and forests in which forests remain as small scattered patches (Asbjornsen et al. 2004; Taubert et al. 2018). The tropical forests in South America underwent a net loss of 2.6 million hectares in the 2010-2020 period, although the deforestation rate has decreased significantly when compared to 2000-2010 (FAO 2020a). More specifically, Ecuador maintained the highest deforestation rates in South America during the periods 1990-2010, with annual rates of between $-1.5 \%$ to $-1.8 \%$ (FAO 2011) and with an overall deforestation of $21,340 \mathrm{~km}^{2}$ between 1990 and 2020 (FAO 2020a). One consequence of this intensive fragmentation is that 47 ecosystems of mainland Ecuador have been classified as very-highly or highly fragmented, i.e. $30 \%$ of the natural areas (Ministerio del ambiente de Ecuador 2015). Those most affected are located in the coastal region, in which there was an area of annual deforestation of $678.13 \mathrm{~km}^{2}$ between 1990 and 2008 (Sierra 2013). The deforestation and degradation of the seasonal dry forests in this region have been particularly intense, thus making them the most threatened type of forest in the country, in addition to being less protected than the evergreen forests (Manchego et al. 2018; Rivas et al. 2020). Deforestation has, in fact, become the greatest threat to seasonal dry forest ecosystems in Ecuador, with an average change in area reduction of $1.4 \%$ per year between 2008 and 2014 (Tapia-Armijos et al. 2015; Manchego et al. 2018). Indeed, tropical dry forests are among the most threatened ecosystems in the world (Hoekstra et al. 2005; Portillo-Quintero and Sánchez-Azofeifa 2010), and are the ecosystems of which the least amount of original surface remains (less than 25\%) (Ferrer-Paris et al. 2018). This deforestation has, according to the IUCN criteria, led the equatorial dry forest to be classified as in critical danger of extinction (Ferrer-Paris et al. 2018), and approximately $70 \%$ of the remaining surface has very high levels of fragmentation (Rivas et al. 2020). Intense deforestation is consequently considered to be the main threat to the biodiversity of the tropical seasonal dry forests of the Tumbension region, which are characterised by a high degree of endemism since they harbour 16 endemic mammals (Loaiza 2013) and 39 endemic bird species (Bird Life International 2019). The Ecuadorian seasonal dry forests contain high levels of floristic diversity, and approximately $80 \%$ of their components are regionally endemic as part of the Tumbesian Endemism Centre (Ministerio del Ambiente del Ecuador 2012). Seasonal dry forest areas also provide local communities with wood and food products, which results in the degradation of the structure, functionality and dynamics of the forest (Ministerio del Ambiente del Ecuador 2012).

Despite the worrying state of conservation, tropical seasonal dry forests have traditionally been studied to a lesser degree than their neighbours, humid forests, with a ratio of approximately one study in dry forests to six in humid forests (Lessmann et al. 2014). One issue that has not been addressed in any great depth is the fragmentation of the Ecuadorian tropical dry forest in the last few decades, and how this fragmentation has transformed the landscape. According to the framework of the Convention on Biological Diversity (Biodiversity Indicators Partnership 2011), international organisations worldwide, such as the EBONE "Europe Biodiversity Observation Nature" (Parr et al. 2010) or the BIP "Biodiversity Indicators Partnership", have recommended analysing ecosystems through the use of fragmentation indices. Class indices separately quantify the quantity and distribution of each type of patch in the landscape, and fragmentation indices can, therefore, be considered for each type of patch (McGarigal and Marks 1995). The objective of this study was consequently to assess the fragmentation of the Ecuadorian seasonal dry forest between 1990 and 2018. The specific objectives of this work were the following: i) to study the deforestation and fragmentation of Ecuadorian seasonal dry forests 
during five different periods $(1990,2000,2008,2014$, 2016 and 2018); ii) to describe the spatial patterns of fragmentation during these study periods; iii) to analyse different parameters of fragmentation (e.g. edge density, number of patches, mean patch size) in the three types of dry forests (deciduous, semi-deciduous and transition forest) in the region between the years 1990-2018; iv) to analyse fragmentation in order to find patterns that indicate the most vulnerable areas; and v) to compare the fragmentation index in protected and unprotected areas. The intention of this was to provide useful information on the state of the Ecuadorian dry forest and the areas with the worst conditions and conservation, which would be useful as regards developing effective protection measures according to the present conservation status and future trends.

\section{Materials and methods}

\section{Study area}

Our study area included the seasonal dry forest in the coastal region of Ecuador (Fig. 1a), also known as Western Ecuador, located along the Pacific Ocean and the west slope of the Andes mountain range. The coastal region is characterised by three large structural elements that influence the distribution patterns of the biota: the Guayas River, the Esmeraldas River and the Coastal mountain range. This region has a total of 24 ecosystems, 22 of which are divided into two biogeographic regions that are clearly distinguishable as regards their composition and floristic structure, in addition to their bioclimate: the predominantly humid region of Chocó and the region of the Equatorial Pacific, which are mostly dry (Ministerio del Ambiente del Ecuador 2013).
Seasonal dry forests in Ecuador thrive in extreme climatic conditions, with an annual rainfall of 400-600 mm in a period of 3-4 months, generally in February, March and April; the average annual temperature is $24.9^{\circ} \mathrm{C}$, and the potential evapotranspiration is $1783 \mathrm{~mm} \cdot \mathrm{year}^{-1}$ (Ministerio del ambiente del Ecuador 2012). In the present study, we considered the seasonal dry forest of the Ecuadorian Pacific, which is divided into deciduous and semi-deciduous areas. In deciduous forests, $75 \%$ of individuals of the arboreal or shrub species lose their leaves during the dry period, which lasts between 6 and 8 months, whereas in the semi-deciduous forest, between $75 \%$ and $25 \%$ of individuals of the arboreal or shrub species lose their leaves and are located in areas in which the dry periods last between 1 to 6 months a year (Prentice 1990; Ministerio del ambiente del Ecuador 2013; Rivas et al. 2020).

\section{GIS sources}

In order to limit the potential extent of the seasonal dry forests, the layers of phenology and land use were obtained from the Ecuadorian Ministry of the Environment (available at http://ide.ambiente.gob.ec/mapainteractivo). Land uses have been obtained by the Ecuadorian Ministry of the Environment, using Landsat satellite images and Advanced Spaceborne Thermal Emission and Reflection Radiometer (ASTER), orthorectification and these have later been certified by experts and by means of fieldwork, with a pixel size of $30 \mathrm{~m}$ (Peralvo and Delgado 2010; Ministerio del Ambiente 2012; MAE and MAGAP 2015; Ministerio del Ambiente 2017). The Kappa index is approximately 0.7 (Ministerio del Ambiente 2012). We selected those land-uses classified
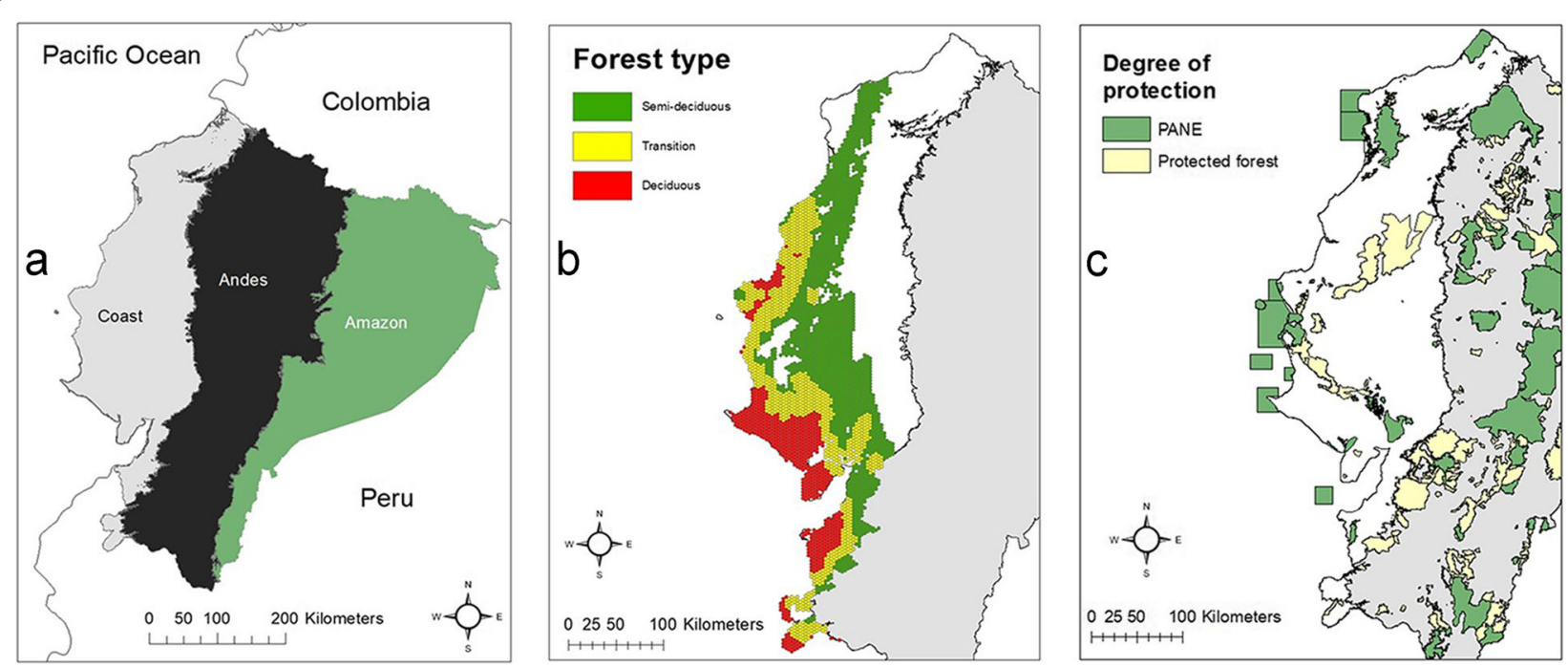

Fig. 1 a Map of continental Ecuador showing its three main geographical regions; b Division of the dry forest by phenologies in hexagons of 10 $\mathrm{km}^{2}$; c Protected areas 
as native forests in zones with a deciduous and semideciduous phenology, since seasonal dry forest predominates in these areas. Flooded areas (mangrove areas) and areas without vegetation cover or without woody vegetation were eliminated. Once the area of seasonal dry forest had been obtained, a transition zone was created between the deciduous and semi-deciduous forest by applying a $10 \mathrm{~km}$ buffer in the area that divided both ecosystems. We eventually obtained three analysis zones: deciduous, semi-deciduous and transition forest (Fig. 1b). Land-uses are available for the years 1990, 2000, 2008, 2014, 2016 and 2018, and they were reclassified into two main land-uses: native forest and non-forest zones. Shrub and Herbaceous Vegetation, Agricultural Land, Body of Water, Anthropic Zone, Other Land, No Information and Forest Plantations were classified as nonforest areas, while the 'native forest' land use was classified as forest (Ministerio del Ambiente 2017).

\section{Deforestation and fragmentation analysis}

We calculated the changes in these two main land-uses throughout the temporal periods. The deforestation rate was calculated by employing the formula proposed by Puyravaud (2003) (Eq. 1).

$$
\begin{aligned}
\text { Deforestation rate }(\mathrm{DR})= & 1 /\left(t_{2}-t_{1}\right) \\
& \times \operatorname{Ln}\left(A_{2} / A_{1}\right) \times 100
\end{aligned}
$$

where $A_{1}$ and $A_{2}$ are the forest cover at times $t_{1}$ and $t_{2}$, respectively.
The study area was divided into $10 \mathrm{~km}^{2}$ tiles (Fig. 1b) made of hexagonal polygons, since this is considered the most suitable geometry when studying interaction and connectivity (Birch et al. 2007). The use of polygons improves the ability to assess landscape metrics in a more homogeneous manner. We selected $10 \mathrm{~km}^{2}$ because $99.8 \%$ of the world's forest fragments cover less than $10 \mathrm{~km}^{2}$ (FAO and PNUMA 2020). One of the three types of forests (deciduous, semi-deciduous, and transition) was assigned to each tile on the basis of the predominant type within each segment. The Patch Analysis Tool (Rempel et al. 2012) in ArcGIS was employed in order to calculate different landscape metrics for each tile (Table 1). These were: Number of patches (NumP), average patch size (MPS), median patch size (MedPS), total edge (TE), and edge density (ED). These parameters were then used to calculate the reticular fragmentation index (RFI) on the basis of the percentage without forest (PSB\%) and the percentage of edge density (ED\%) (Table 1), using the formula proposed by Leautaud Valenzuela (2014). A 1990 forest fragment of 0.2 ha was used as a reference value in order to determine $100 \%$ of the PSB\% and ED\% metrics. This size was used because smaller sizes distorted the calculation. The RFI was divided into five categories: very high $(>80 \%)$, high $(60 \%-80 \%)$, medium $(40 \%-$ $60 \%)$, low $(40 \%-20 \%)$ and very low $(<20 \%)$. An RFI of $100 \%$ was attributed to those tiles from which the native forest had disappeared.

Table 1 Description of the fragmentation metric parameters analysed according to McGarigal and Marks (1995) and Leautaud

\begin{tabular}{|c|c|c|c|}
\hline Parameter & Abbreviation & Definition & Unit \\
\hline Number of Patches & NumP & $\begin{array}{l}\text { Total number of patches inside the tiles. The more patches there are, the more fragmented the } \\
\text { forest is considered to be. }\end{array}$ & Number \\
\hline Mean patch size & MPS & $\begin{array}{l}\text { The average patch size of the forest within the tile. } \\
\text { A smaller average forest patch size is considered indicative of a more fragmented forest. }\end{array}$ & $\mathrm{km}^{2}$ \\
\hline Median patch size & MedPS & $\begin{array}{l}\text { The middle patch size, or 50th percentile of the forest patches inside the tile. } \\
\text { Median patch size can hide the presence of very large or very small patches. }\end{array}$ & $\mathrm{km}^{2}$ \\
\hline Total edge & TE & $\begin{array}{l}\text { Perimeter of patches within each tile. The greater the perimeter, the more exposed to } \\
\text { disturbances. Greater TE patch may be associated with more fragmented forests (if the } \\
\text { fragmentation is related to an anthropogenic disturbance) }\end{array}$ & $\mathrm{km}$ \\
\hline Edge density & ED & $\begin{array}{l}\text { Amount of edge }(\mathrm{km}) \text { relative to the forest area }\left(\mathrm{km}^{2}\right) \text { within the tile. } \\
\mathrm{ED}=\mathrm{TE} / \text { Forest area within the tile } \\
\text { A high ratio of perimeter to forest patch area may be associated with more fragmented forests (if } \\
\text { fragmentation is related to anthropogenic disturbance). }\end{array}$ & $\mathrm{km} \cdot \mathrm{km}^{-2}$ \\
\hline $\begin{array}{l}\text { Edge density } \\
\text { percentage }\end{array}$ & $\mathrm{ED}$ & $\begin{array}{l}\text { Edge percentage relative to landscape area. } \\
\text { A high ratio of perimeter to forest patch area may be associated with more fragmented forests (if } \\
\text { fragmentation is related to anthropogenic disturbance). }\end{array}$ & Percentage \\
\hline $\begin{array}{l}\text { Percentage without } \\
\text { forest }\end{array}$ & PSB & $\begin{array}{l}\text { Non-forest area (\%) without forest within the tile. } \\
\text { Higher percentage of area without forest within the tile would indicate greater fragmentation. }\end{array}$ & Percentage \\
\hline $\begin{array}{l}\text { Reticular } \\
\text { fragmentation } \\
\text { index }\end{array}$ & RFI & $\begin{array}{l}\text { Reticular fragmentation index of each tile. } \\
\mathrm{RFI}=(\mathrm{PSB} \%+\mathrm{ED} \%) / 2 \\
\mathrm{~A} \text { higher RFI signifies a greater percentage of fragmentation within the tile. }\end{array}$ & Percentage \\
\hline
\end{tabular}
Valenzuela (2014) 


\section{Fragmentation patterns}

The fragmentation patterns were described by employing the Getis-Ord $\mathrm{Gi}^{*}$ analysis (Ord and Getis 1995) for the years 1990 and 2018 and by considering the RFI values. The resulting $Z$-scores and $p$-values indicate a spatial cluster of high or low RFI values. At $5 \%$ significance $(p \leq 0.05)$, a $Z$-score greater than 1.96 indicates a hot spot, while a $Z$-score smaller than -1.96 indicates a cold spot and the remaining values are classified as not significant $(-1.96<Z<1.96 ; p>0.05)$, thus suggesting a random spatial process (Feng et al. 2018). A transition matrix was created using the categories of the Getis-Ord $\mathrm{Gi}^{*}$ analysis for the years 1990 and 2018 to identify the probability of a hexagon disappearing or of its state changing, based on its initial state (1990) upon its categorisation.

\section{Fragmentation in protected and unprotected areas}

In order to test the trend of the RFI in protected and unprotected areas (Fig. 1c), an RFI trend index was calculated as follows (Eq. 2):

$$
\text { RFI trend index }=\left(\mathrm{RFI}_{2018}-\mathrm{RFI}_{1990}\right) / \mathrm{RFI}_{1990}
$$

We then assigned one of the following three protection categories to each tile: unprotected, protected by the Heritage of Natural Areas of the Ecuadorian State (PANE in Spanish), and Protected forests. The RFI trend index of these three categories was then compared in order to verify whether the degree of protection prevents fragmentation more effectively.

\section{Statistical analysis}

Wilcoxon paired tests were then used to compare the value of the fragmentation indicators (RFI, NumP, MPS, MedPS, TE, and DE), which were considered as dependent variables, between 1990 and 2018 in each of the three types of forest (deciduous, semi-deciduous and transition). The tiles were employed to pair these tests in order to consider the variations among the same grids between the two periods. A Kruskal-Wallis test was used to compare the RFI values (dependent variable) obtained for the three types of forest in the year 2018. The same type of test was similarly used to compare the RFI trend indices (dependent variable) obtained for the three categories of protection (unprotected, PANE, and Protected forests). In both the Kruskal-Wallis tests, pairwise comparisons (post hoc) were developed in order to verify the differences among the levels of the independent variables. The tiles were the experimental units in all the statistical analyses. InfoStat software was used in all the statistical analyses.

\section{Results}

\section{Evolution of loss and fragmentation of forest}

Since 1990, $2631.91 \mathrm{~km}^{2}$ has been lost (Table 2), which signifies a loss of $27.04 \%$ of the original surface still remaining in 1990, and an annual deforestation rate of $94 \mathrm{~km}^{2}(-1.12 \%)$.

This deforestation has changed the degree of fragmentation of the dry forest (Table 3 and Fig. 2), since the mean and median RFI values have increased, particularly from 1990 to 2008 (Table 3). In 1990, 42.28\% of the tiles of seasonal dry forest were classified with a low or very low RFI, while this figure dropped to $29.15 \%$ in 2018 . Moreover, 432 tiles that had some forest patches in 1990 had no patches in 2018.

\section{Spatial evolution of fragmentation}

Deforestation has occurred principally in the north of the study area, which formally contained small forest fragments that have disappeared or been considerably reduced since 1990 (Figs. 2 and 3). Other affected areas were located in the Guayas areas and in the centralsouth, where many of the segments had disappeared, leading to a significant increase in RFI. The edge areas of the large forest fragments have been deforested, as has also occurred with the small fragments, which has resulted in the disappearance of those forests throughout the territory analysed (Fig. 3).

\section{Fragmentation indexes for the three types of forests}

According with the Wilcoxon paired tests, the RFI value was significantly higher in 2018 than in 1990 for the three types of forests (Table 4), and the NumP, MPS, MedPS and TE values were significantly higher in 1990 than in 2018. The ED was significantly higher in 2018 than in 1990 for the semi-deciduous and transition forests, whereas it was lower in 2018 for deciduous forests (Table 4). The semi-deciduous forest attained the highest increase in RFI from 1990 to 2018 (highest mean difference), with the highest levels of fragmentation occurring in 2018 (Table 4). With regard to the number

Table 2 Surface of equatorial dry native forest and other land uses in each of the periods included in this study

\begin{tabular}{lllllll}
\hline & $\mathbf{1 9 9 0}$ & $\mathbf{2 0 0 0}$ & $\mathbf{2 0 0 8}$ & $\mathbf{2 0 1 4}$ & $\mathbf{2 0 1 6}$ & $\mathbf{2 0 1 8}$ \\
\hline Native Forest $\left(\mathrm{km}^{2}\right)$ & 9730.91 & 8848.42 & 7931.61 & 7497.77 & 7276.01 & 7099.26 \\
Other land uses $\left(\mathrm{km}^{2}\right)$ & $17,973.63$ & $18,856.12$ & $19,772.94$ & $20,206.78$ & $20,428.55$ & $20,605.30$ \\
Deforestation rate & - & -0.95 & -1.38 & -0.94 & -1.50 & -1.23 \\
\hline
\end{tabular}


Table 3 Variation of the mean and median RFI values (\%) per tile in each of the 6 periods. SD = standard deviation

\begin{tabular}{|c|c|c|c|c|c|c|c|}
\hline & & 1990 & 2000 & 2008 & 2014 & 2016 & 2018 \\
\hline \multirow[t]{3}{*}{$\mathrm{RFI}$} & Mean & 40.65 & 46.82 & 51.62 & 50.98 & 51.62 & 52.26 \\
\hline & SD & 21.42 & 26.75 & 29.33 & 27.38 & 27.38 & 27.47 \\
\hline & Median & 44.9 & 48.57 & 50.17 & 50.55 & 50.76 & 51.11 \\
\hline
\end{tabular}

of patches (NumP) within the tile, this has not undergone a great variation as regards either the total or forest types.

The Kruskal-Wallis test showed differences among the RFI values obtained for the three types of seasonal dry forests in $2018(H=295.65 ; p<0.0001)$, with the highest value being attained for semi-deciduous forest and the lowest for the transition forest (Table 5).

\section{Fragmentation patterns}

The Getis-Ord $\mathrm{Gi}^{*}$ analysis shows the hot and cold fragmentation spots (Fig. 4). These results indicate that the hot areas, which had a worse structural connectivity, were more vulnerable to disappearance and had a worse state of conservation. The comparison of 1990 with 2018 highlights this evolution (Fig. 4 and Table 6). In 2018, there were $981(29.70 \%)$ tiles catalogued as cold spots, 1044 (31.60\%) with no significant differences, and 843 (25.52\%) as hotspots; in 1990, meanwhile, there were 1063 (32.18\%), 1286 (38.93\%) and 863 (26.12\%) respectively. The transition matrix (Table 6) shows that of the 863 tiles classified as hotspots in 1990, 213 (24.68\%) disappeared during the studied period, and 572 (66.28\%) remained in the hotspot category.
Fragmentation in protected and unprotected areas Of the 2707 tiles into which the seasonal dry forest was divided, only $7.24 \%$ was covered by PANE and $8.32 \%$ by protected forests, while $84.45 \%$ were unprotected. The RFI trend was significantly different for the three protection categories $(H=19.60 ; p<0.001)$, with the lowest value for PANE $(0.3 \pm 0.07)$, the highest values for Protected forests $(0.97 \pm 0.17)$, and the intermediate values for unprotected areas $(0.42 \pm 0.03)$.

\section{Discussion}

Ecuador is undergoing a high rate of deforestation, and the seasonal dry forest is no exception (Sierra 2013). Our results show that $2631.91 \mathrm{~km}^{2}$ of seasonal dry forest have been converted to other land uses in the last three decades $(87 \%$ of the forest that was deforested between 1990 and 2018 had been transformed into agricultural land by 2018, while 7\% had been transformed into scrubland), with the extinction of many patches, thus causing a constant increase in fragmentation. This fragmentation has occurred throughout the study area, although we have identified areas with higher fragmentation values and that are spatially aggregated (hotspots), thus suggesting that an important area of the remaining forests runs a high risk of disappearing in the next few years. All these data suggest the urgency of implementing effective conservation measures to preserve the remaining Ecuadorian seasonal dry forest patches and promoting connectivity, with the eventual goal of preventing the disappearance of new areas and ensuring the functional ecology of the remaining forests.

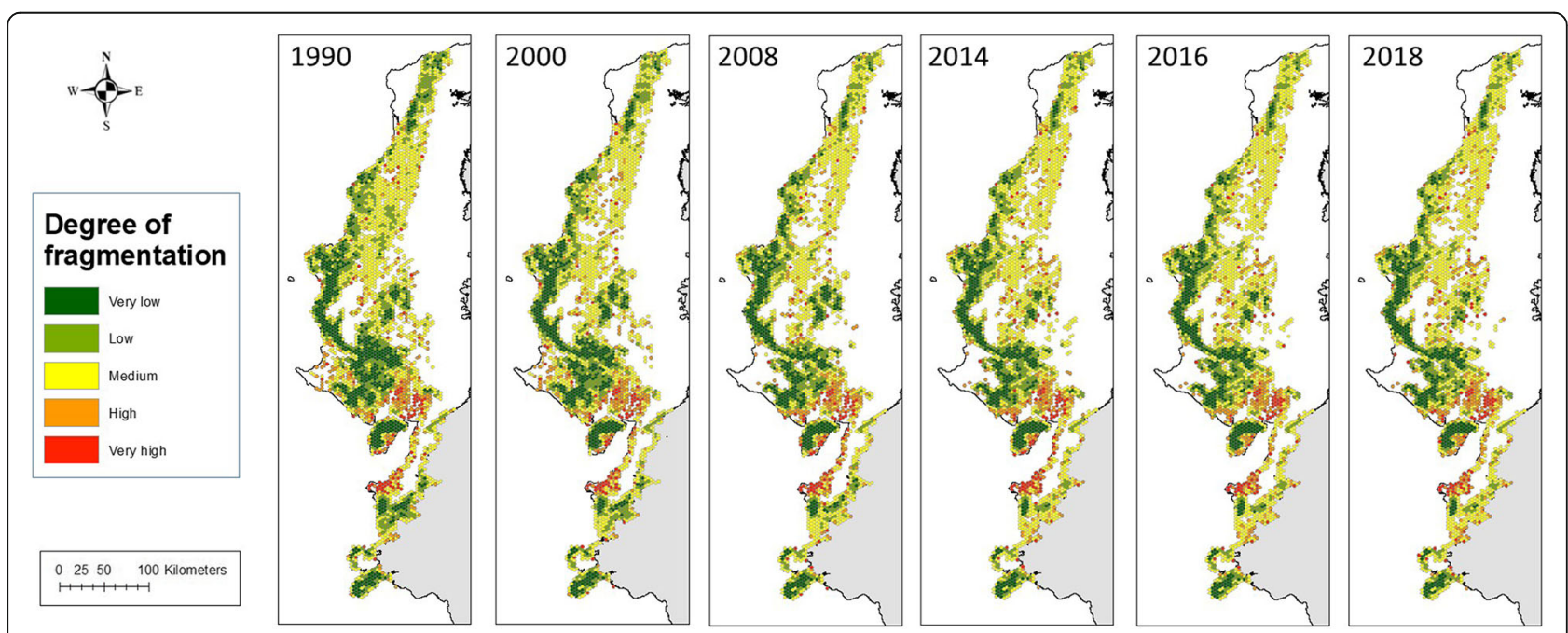

Fig. 2 Spatial evolution of the RFI of the equatorial dry forest per tile in each of the six time periods 

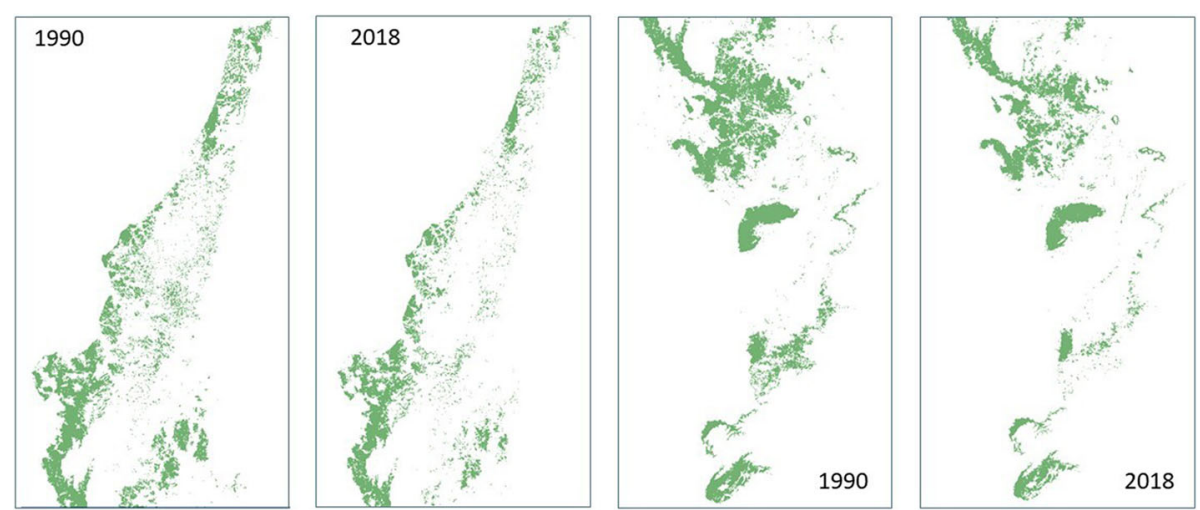

Fig. 3 Comparison of the central north and central south of the Ecuadorian coast, showing details of forest fragments (green areas) in the years 1990 and 2018

\section{Deforestation of Ecuadorian seasonal dry forests}

We observed a dramatic level of deforestation of native forests, and consequently assume that this is a threat to the flora and fauna that inhabit these forests. According to our results, the Ecuadorian seasonal dry forests underwent a net loss of 27\% from 1990 to 2018, signifying an annual deforestation rate of $-1.12 \%$. This annual deforestation rate was higher than the rates found in other Latin American countries (Brazil: - 0.56\%; Colombia: $-0.31 \%$; Peru: $-0.18 \%)$, but lower than that of Paraguay (-1.53\%) (FAO 2020b). When compared to other dry forests in the region, the deforestation rate was in the same range as that of Paraguay and Chile (between $-1 \%$ and $-2 \%$ ), with lower rates than those found for Argentina and Mexico (> $-2 \%$ ), but greater than those found for Brazil, Costa Rica and Venezuela $(<-$ 1\%) (Armenteras et al. 2017).

\section{Fragmentation}

According to our calculations, all the landscape metrics attained worse fragmentation values in 2018 than in 1990 for all three types of forest. The number of patches decreased and the forests had a smaller mean patch size, which led to an overall increase in the fragmentation index (RFI). But if this information is analysed together with the other fragmentation metrics, it will be noted that this is associated with the disappearance of the smaller patches and the fragmentation of large patches, which has kept the number of patches constant, but has increased the fragmentation. The edge density (ED) in the semi-deciduous and transitional forest has probably increased as a consequence of the forest fragments getting smaller (lower mean MPS) and the increase in the number of small fragments (median MPS). However, the ED in the deciduous forest is probably decreasing because the small fragments are disappearing and the largest ones are becoming smaller (thus keeping the MPS constant), and since smaller fragments had higher edge density values, their disappearance may have led to a decrease in the ED value (Hargis et al. 1998). This process makes this measure less sensitive because, although these small patches disappear, the landscape fragmentation increases (Whelan and Maina 2005; Tulloch et al. 2016). Small patches have been shown to be fundamental to ecosystems, particularly in those that are highly fragmented, and their disappearance may, therefore, have negative consequences for them (Tulloch et al. 2016).

Of the three types of forest considered, the semideciduous forest was the most fragmented. For instance, the average patch size (MPS) of the semi-deciduous forest attained very worrying values $\left(0.58 \mathrm{~km}^{2}\right)$, considering that the tile area is $10 \mathrm{~km}^{2}$. This may be owing to the fact that the more humid forests are more fertile and are, therefore, more prone to the establishment of crops and pastures (Ministerio del ambiente del Ecuador 2012; Lessmann et al. 2014). Moreover, many areas of seasonal dry forest have degenerated into savannah, scrub or grasslands owing to the high pressure of livestock and overgrazing, which could be the cause of the disappearance of the small fragments of deciduous forest, thus limiting forest growth and extension (Trejo and Dirzo 2000; Sales et al. 2020). Conversely, drier areas are often perceived as areas that are poorer in resources (Siyum 2020), which could explain the lower conversion of the deciduous forest when compared to the semi-deciduous forest.

\section{Connectivity}

Upon comparing the images from 1990 and 2018 (Figs. 2, 3 and 4), it will be noted that a quarter of the forest fragments classified as hotspots in 1990 had completely disappeared by 2018 , which indicates that these areas are more prone to disappearance. Many factors may lead to differences in deforestation among areas, such as the growth rates of the local 
Table 4 Variation between 1990 and 2018 as regards the values obtained for the different fragmentation indicators by forest type, showing the $Z$ and $p$-value from the Wilcoxon paired test. Mean-dif = value 2018 - value 1990; SD = standard deviation

\begin{tabular}{|c|c|c|c|c|c|c|c|}
\hline \multirow{2}{*}{$\begin{array}{l}\text { Forest type } \\
\text { Year }\end{array}$} & & \multicolumn{2}{|c|}{ Deciduous } & \multicolumn{2}{|c|}{ Semi-deciduous } & \multicolumn{2}{|c|}{ Transition } \\
\hline & & 1990 & 2018 & 1990 & 2018 & 1990 & 2018 \\
\hline \multirow[t]{6}{*}{ RFI (\%) } & Mean & 39.14 & 49.75 & 45.92 & 59.47 & 33.94 & 42.99 \\
\hline & SD & 27.34 & 32.96 & 16.17 & 23.34 & 22.22 & 26.79 \\
\hline & Median & 42.18 & 49.12 & 49.1 & 54.07 & 33.73 & 42.56 \\
\hline & Mean-dif ( \pm SD) & \multicolumn{2}{|c|}{$11.20( \pm 19.18)$} & \multicolumn{2}{|c|}{$16.53( \pm 24.17)$} & \multicolumn{2}{|c|}{$9.58( \pm 17.45)$} \\
\hline & Z & \multicolumn{2}{|l|}{15.08} & \multicolumn{2}{|l|}{28.32} & \multicolumn{2}{|l|}{20.34} \\
\hline & $p$-value & \multicolumn{2}{|c|}{$p<0.0001$} & \multicolumn{2}{|c|}{$p<0.0001$} & \multicolumn{2}{|c|}{$p<0.0001$} \\
\hline \multirow[t]{7}{*}{ NumP } & $n$ & 595 & 511 & 1528 & 1334 & 1089 & 1021 \\
\hline & Mean & 7.48 & 7.39 & 5.72 & 5.14 & 5.58 & 4.73 \\
\hline & SD & 10.79 & 11.62 & 7.15 & 7.25 & 6.93 & 6.51 \\
\hline & Median & 3 & 3 & 4 & 3 & 3 & 3 \\
\hline & Mean-dif ( \pm SD) & \multicolumn{2}{|c|}{$-1.11( \pm 5.26)$} & \multicolumn{2}{|c|}{$-1.15( \pm 4.30)$} & \multicolumn{2}{|c|}{$-1.13( \pm 4.86)$} \\
\hline & Z & \multicolumn{2}{|l|}{-7.02} & \multicolumn{2}{|c|}{-11.26} & \multicolumn{2}{|c|}{-8.51} \\
\hline & $p$-value & \multicolumn{2}{|c|}{$p<0.0001$} & \multicolumn{2}{|c|}{$p<0.0001$} & \multicolumn{2}{|c|}{$p<0.0001$} \\
\hline \multirow[t]{6}{*}{ MPS $\left(\mathrm{km}^{2}\right)$} & Mean & 2.34 & 2.35 & 0.92 & 0.58 & 2.51 & 2.15 \\
\hline & SD & 3.55 & 3.40 & 1.90 & 1.46 & 3.36 & 3.06 \\
\hline & Median & 0.35 & 0.47 & 0.17 & 0.12 & 0.72 & 0.64 \\
\hline & Mean-dif ( \pm SD) & \multicolumn{2}{|c|}{$-0.31( \pm 1.88)$} & -0.38 & & -0.49 & \\
\hline & Z & -8.03 & & -18.00 & & -9.21 & \\
\hline & $p$-value & $p<0.0$ & & $p<0 . c$ & & $p<0$ & \\
\hline $\operatorname{MedPS}\left(\mathrm{km}^{2}\right)$ & Mean & 2.11 & 2.16 & 0.76 & 0.47 & 2.24 & 1.91 \\
\hline & SD & 3.64 & 3.48 & 1.92 & 1.46 & 3.49 & 3.16 \\
\hline & Median & 0.02 & 0.07 & 0.05 & 0.05 & 0.08 & 0.14 \\
\hline & Mean-dif ( \pm SD) & -0.25 & & -0.32 & & -0.43 & \\
\hline & Z & -4.59 & & -11.30 & & -5.42 & \\
\hline & $p$-value & $p<0.0$ & & $p<0 . c$ & & $p<0$ & \\
\hline TE (km) & Mean & 15.42 & 15.01 & 15.59 & 11.91 & 20.90 & 18.02 \\
\hline & SD & 12.14 & 10.91 & 12.59 & 10.67 & 12.85 & 11.76 \\
\hline & Median & 13.39 & 13.73 & 12.83 & 8.73 & 20.21 & 17.15 \\
\hline & Mean-dif ( \pm SD) & -2.48 & & -4.86 & & -3.94 & \\
\hline & $Z$ & -6.6 & & -18.57 & & -10.2 & \\
\hline & $p$-value & $p<0.0$ & & $p<0.0$ & & $p<0$ & \\
\hline $\mathrm{ED}\left(\mathrm{km} \cdot \mathrm{km}^{-2}\right)$ & Mean & 42.92 & 35.57 & 20.04 & 29.52 & 23.26 & 31.51 \\
\hline & SD & 259.28 & 106.75 & 45.19 & 74.97 & 97 & 214 \\
\hline & Median & 7.05 & 9.02 & 13.02 & 17.43 & 7.13 & 8.72 \\
\hline & Mean-dif ( \pm SD) & -7.35 & & 9.49 & & 8.26 & \\
\hline & $z$ & 6.04 & & 16.71 & & 10.03 & \\
\hline & $p$-value & $p<0.0$ & & $p<0.0$ & & $p<0$ & \\
\hline
\end{tabular}

human population, the presence of particular hardwood species, the development of specific types of agriculture, the distance to roads and trails, the distance to rivers or the suitability of the land (e.g. soil features or being steep) for agricultural purposes in general (Andam et al. 2008; Barber et al. 2014; van Der Hoek 2017). Future studies should, therefore, be carried out to evaluate which factors explain a greater or lesser fragmentation of the landscape in order to identify those forests that are still well 
Table 5 RFI values in 2018 for the three types of forests. $N=$ number of tiles; $\mathrm{SE}=$ standard error of means. Lower case letters indicate significant differences according to the post hoc test

\begin{tabular}{lllll}
\hline Kind of forest & $\boldsymbol{N}$ & Mean & SE & Median \\
\hline Deciduous & 608 & $49.75^{\mathrm{a}}$ & 1.19 & 49.12 \\
Semi-deciduous & 1634 & $59.47^{\mathrm{b}}$ & 0.40 & 54.07 \\
Transition & 1106 & $42.99^{\mathrm{c}}$ & 0.69 & 42.65 \\
\hline
\end{tabular}

conserved and run the greatest risk of becoming fragmented.

Deforestation for agricultural and livestock purposes has been identified as one of the main reasons for the loss of seasonal dry forests in Ecuador (Tapia-Armijos et al. 2015; Prieto-Torres et al. 2018), and this also occurs in other countries, such as in the Brazilian Cerrado (Trigueiro et al. 2020) or in the Mexican Yucatan (Smith et al. 2019), and in other dry forests in Latin America (Armenteras et al. 2017). The spatial analysis of fragmentation indicates two large areas of high concentrations of fragmentation (hotspots) in Ecuadorian seasonal dry forests (Fig. 4). The first area is located in the province of Manabí, which is the province with the highest agricultural production, and in which 777,088 ha correspond to cultivated and natural pastures, contributing more than $20 \%$ of the country's agricultural area (INEC 2019). The second fragmented area corresponds to the urban areas of Guayaquil and Machala, the first and third largest cities as regards human population, respectively (Instituto nacional de estadisticas y censos 2010).
The population of Ecuador has increased dramatically in the last few decades, since it has grown by $452 \%$ in 60 years (Villacís and Carrillo 2012), reaching 17 million inhabitants in 2019 (Instituto Nacional de Estadística 2019). This has led to an increase in demands for food and an increase in the areas devoted to agricultural and livestock production, which are the greatest threats to tropical forests in South America and Africa (Laurance et al. 2014). The dry forests are used by the local population, since they have environmental, social and economic importance for various segments of the rural communities (Briceño et al. 2016). The quality of wood products has historically led to interventions in these forests in order to extract wood and food products as a means of subsistence. The seasonal dry forest provides essential ecosystem goods and services, livelihoods and is vital to the well-being of its residents, since it provides supplies (water, wood, food, biofuels) (Nelson et al. 2020; Siyum 2020). Population growth consequently also increases the pressure on remnants of forest. In summary, the great importance of agriculture for the economy of the region, together with the growth of the human population, have increased the conversion of natural forests into agricultural land, thus leading to a rise in fragmentation.

The analyses of hotspots showed the areas with a worst conservation status, low connectivity and high fragmentation, and these may be priority areas for forest restoration and an increase in connectivity. Furthermore, in areas identified as cold spots, the actions should be
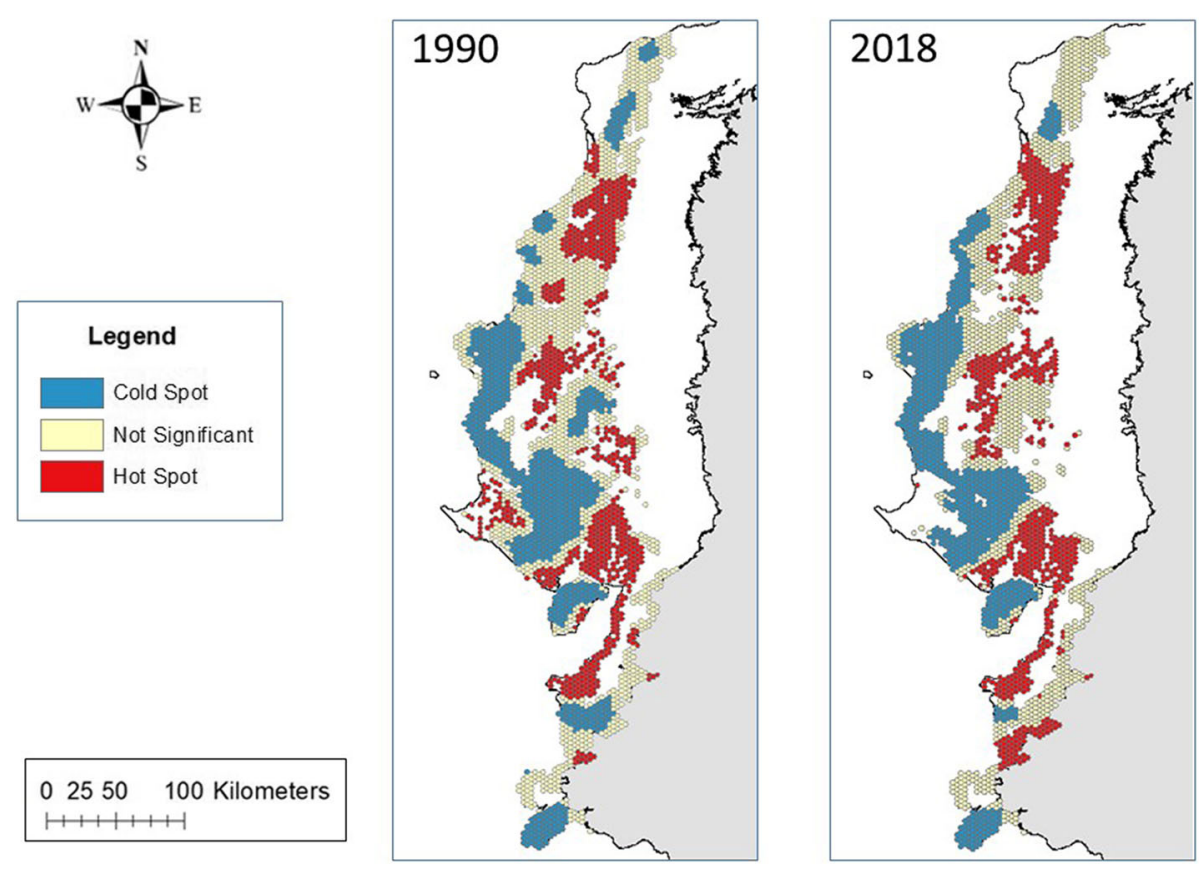

Fig. 4 Comparison of the hot and cold spots by means of Getis-Ord Gi* analysis in the years 1990 and 2018 
Table 6 Transition matrix according to the categorisation provided by the Getis-Ord Gi* analysis, showing the number of tiles whose state changed from 1990 (columns) to 2018 (rows). NS = not significant changes

\begin{tabular}{lllllll}
\hline \multirow{2}{*}{ Category } & & $\mathbf{2 0 1 8}$ & & & & \\
\cline { 2 - 5 } & Cold & NS & Hot & No forest & Total \\
\hline 1990 & Cold & 823 & 202 & 14 & 24 & 1063 \\
& NS & 154 & 736 & 198 & 198 & 1286 \\
& Hot & 0 & 78 & 572 & 213 & 863 \\
& Forested & 4 & 28 & 59 & 0 & 91 \\
& Total & 981 & 1044 & 843 & 435 & 3303 \\
\hline
\end{tabular}

focused principally on preventing deforestation. Fragmentation can have negative consequences for populations of wild species that inhabit the dry forest (Solórzano et al. 2021), since many remaining patches are becoming isolated and exposed to disappearance (Margules and Pressey 2000). The synergistic effects of fragmentation lead to changes in climate, which can, in turn, change the structure of the vegetation, soil cover and nutrient status, thus affecting the species that inhabit these forest fragments (Margules and Pressey 2000). Changes take place in these isolated fragments, which can lead to the collapse of populations (Laurance et al. 2012).

\section{Conservation implications}

Tropical seasonal dry forests are the ecosystems with the least remaining surface in Ecuador (Ferrer-Paris et al. 2018) and are possibly the most threatened tropical ecosystems in the world (Escribano-Avila et al. 2017). They are considered an endangered ecosystem owing to the high degree of endemism and species richness; however, less than $10 \%$ of their area is protected (Prieto-Torres et al. 2018). Protected areas are important for conservation (Barber et al. 2014; van Der Hoek 2017), and should be expanded in the case of the Ecuadorian dry forest (see below), which is less protected than other ecosystems (Rivas et al. 2020).

Previous works have shown that the dry ecosystems in the Coastal Region of Ecuador are underrepresented in the PANE (Sierra et al. 2002; Lessmann et al. 2014; Escribano-Avila et al. 2017), thus suggesting that it is necessary to create new protected areas in order to preserve these ecosystems (Lessmann et al. 2014; Cuesta et al. 2017). As our results show, there has been less fragmentation in the PANE, while it has increased more in unprotected areas and has been particularly dramatic in protected forests. The protected areas included in the PANE have, therefore, been partly effective as regards preventing deforestation, with a smaller increase in the RFI value than in unprotected areas from 1990 to 2018. These results coincide with those of two previous works, which demonstrated that the deforestation rates were lower inside protected areas, although deforestation still took place in those areas (van Der Hoek 2017; Ford et al. 2020). Protected forests are not, however, an effective conservation tool for the conservation of seasonal dry forests since, according our results, the RFI increased even more than in unprotected areas. Indeed, more than half of the areas in protected forests were classified as non-forest land use (Rivas et al. 2020). Although intensive agriculture and deforestation is prohibited in those forests (Sandoval et al. 2017), our results showed that the RFI dramatically increased inside the protected forests, signifying that the current management system of these forests needs to be reviewed with the aim of ensuring their intended conservation goals. Protection measures should, therefore, be implemented, and they should be established in areas of high priority, which would reduce fragmentation and increase structural connectivity. Several scientists have recently highlighted the importance of small forest patches in fragmented landscapes as regards biodiversity conservation (Tulloch et al. 2016; Fahrig et al. 2019; Volenec and Dobson 2020), thus suggesting that it is necessary to maximize the total amount of habitat conserved, irrespective of its rate of fragmentation (Fahrig et al. 2019; Ríos et al. 2021). Specific conservation measures, such as the creation of small reserves (including private protected areas: Guerrero-Casado et al. 2021), should, therefore, be implemented in order to protect the few remnants of seasonal dry forest.

\section{Conclusion}

According to our results, the Equatorial seasonal dry forest has undergone a continuous process of deforestation that has led to the loss of more than $2600 \mathrm{~km}^{2}$ of native dry forest in the last three decades, which is causing an increase in fragmentation, with semi-deciduous forest being the most affected. Fragmentation has increased since 1990, and the number of patches has decreased as a result of the reduction in the forest area, thus increasing the border and patching the forest in isolated fragments, and consequently making it more exposed to anthropic and natural changes. Fragmentation occurs throughout the entire distribution area of seasonal dry forest, which degrades the ecosystem, increases its vulnerability, reduces the area and decreases its connectivity, thus leading to high values of biodiversity loss. Our results show that many areas of seasonal dry forests run a great risk of disappearing if effective protection is not provided or conservation measures are not taken, and it is, therefore, urgent to establish conservation measures that will avoid the continued fragmentation of these forests. 


\section{Supplementary Information}

The online version contains supplementary material available at https://doi. org/10.1186/s40663-021-00329-5.

Additional file 1: Figure S1. Percentage of RFI per tile between the years 1990 and 2018 for the following values: disappeared, very high, high, medium, low and very high.

\section{Acknowledgements}

José Guerrero-Casado is currently supported by the European Regional Development Fund (ERDF) and the Consejería de Transformación Económica, Industria, Conocimiento y Universidades (project reference: 1264483-R). Rafael M Navarro Cerrillo is particularly grateful for the support of the ISOPINE (UCO-1265298) and ESPECTRAMED (CGL2017-86161-R) projects. We acknowledge the institutional support of the University of Cordoba-Campus de Excelencia CEIA3.

\section{Authors' contributions}

Carlos A. Rivas: data collection, experimental design and writing the origina draft. José Guerrero-Casado: statistical analysis, supervision, review and editing the original draft. Rafael M. Navarro-Cerillo: experimental design, conceptualisation, supervision, review and editing the original draft. The author(s) read and approved the final manuscript.

\section{Funding}

José Guerrero-Casado is currently supported by the European Regional Development Fund (ERDF) and the Consejería de Transformación Económica, Industria, Conocimiento y Universidades (project reference: 1264483-R). Rafael M Navarro Cerrillo is particularly grateful for the support of the ISOPINE (UCO-1265298) and ESPECTRAMED (CGL2017-86161-R) projects.

\section{Availability of data and materials}

The datasets used and/or analysed during the current study are available from the corresponding author on reasonable request.

\section{Declarations}

Ethics approval and consent to participate

Not applicable.

\section{Consent for publication}

Not applicable.

\section{Competing interests}

The authors declare that they have no competing interests.

\section{Author details}

${ }^{1}$ Instituto de Ciencias Básicas, Universidad Técnica de Manabí, Portoviejo, Manabí, Ecuador. ${ }^{2}$ Department of Forest Engineering, Laboratory of Dendrochronology, Silviculture and Global Change - DendrodatLab - ERSAF, University of Cordoba, Campus de Rabanales, Crta. IV, km. 396, E-14071 Cordoba, Spain. ${ }^{3}$ Departamento de Medicina Veterinaria, Facultad de Ciencias Veterinarias, Universidad Técnica de Manabí, Portoviejo, Manabí, Ecuador. ${ }^{4}$ Department of Zoology, University of Cordoba, Campus de Rabanales, 14071 Cordoba, Spain.

Received: 31 January 2021 Accepted: 14 June 2021

Published online: 11 July 2021

\section{References}

Andam KS, Ferraro PJ, Pfaff A, Sanchez-Azofeifa GA, Robalino JA (2008) Measuring the effectiveness of protected area networks in reducing deforestation. PNAS 105(42):16089-16094. https://doi.org/10.1073/pnas.0800437105

Armenteras D, Espelta JM, Rodríguez N, Retana J (2017) Deforestation dynamics and drivers in different forest types in Latin America: three decades of studies (1980-2010). Glob Environ Chang 46:139-147. https://doi.org/10.101 6/j.gloenvcha.2017.09.002

Asbjornsen H, Ashton MS, Vogt DJ, Palacios S (2004) Effects of habitat fragmentation on the buffering capacity of edge environments in a seasonally dry tropical oak forest ecosystem in Oaxaca, Mexico. Agric Ecosyst Environ 103(3):481-495. https://doi.org/10.1016/j.agee.2003.11.008

Barber CP, Cochrane MA, Souza CM, Laurance WF (2014) Roads, deforestation, and the mitigating effect of protected areas in the Amazon. Biol Conserv 177:203-209. https://doi.org/10.1016/j.biocon.2014.07.004

Biodiversity Indicators Partnership (2011) Guidance for national biodiversity indicator development and use. UNEP World Conservation Monitoring Centre, Cambridge, p 40

Birch CPD, Oom SP, Beecham JA (2007) Rectangular and hexagonal grids used for observation, experiment and simulation in ecology. Ecol Model 206(3-4): 347-359. https://doi.org/10.1016/j.ecolmodel.2007.03.041

Bird Life International (2019) BirdLife data zone. http://datazone.birdlife.org/eba/fa ctsheet/47. Accessed 16 Nov 2019.

Briceño J, Iniguez-Gallardo V, Ravera F (2016) Factores que influyen en la apreciación de servicios de los ecosistemas de los bosques secos del sur del Ecuador. Rev Ecosistemas 25(2):46-58. https://doi.org/10.7818/ECOS.2016.2 $5-2.06$

Chakraborty A, Ghosh A, Sachdeva K, Joshi PK (2017) Characterizing fragmentation trends of the Himalayan forests in the Kumaon region of Uttarakhand, India. Ecol Inform 38:95-109. https://doi.org/10.1016/j.ecoinf.201 6.12 .006

Cuesta F, Peralvo M, Merino-Viteri A, Bustamante M, Baquero F, Freile JF, Muriel P, Torres-Carvajal O (2017) Priority areas for biodiversity conservation in mainland Ecuador. Neotrop Biodivers 3(1):93-106. https://doi.org/10.1080/23 766808.2017.1295705

Escribano-Avila G, Cervera L, Ordóñez-Delgado L, Jara-Guerrero A, Amador L, Paladines B, Briceño J, Parés-Jiménez V, Lizcano DJ, Duncan DH, Iván Espinosa C (2017) Biodiversity patterns and ecological processes in Neotropical dry forest: the need to connect research and management for long-term conservation. Neotrop Biodivers 3(1):107-116. https://doi.org/10.1 080/23766808.2017.1298495

Fahrig L (2003) Effects of habitat fragmentation on biodiversity. Annu Rev Ecol Evol Syst 34(1):487-515. https://doi.org/10.1146/annurev.ecolsys.34.011 802.132419

Fahrig L, Arroyo-Rodríguez V, Bennett JR, Boucher-Lalonde V, Cazetta E, Currie DJ, Eigenbrod F, Ford AT, Harrison SP, Jaeger JAG, Koper N, Martin AE, Martin J-L, Metzger JP, Morrison P, Rhodes JR, Saunders DA, Simberloff D, Smith AC, Tischendorf L, Vellend M, Watling JI (2019) Is habitat fragmentation bad for biodiversity? Biol Conserv 230:179-186. https://doi.org/10.1016/j.biocon.201 8.12 .026

FAO (2011) State of the World's forests 2011. Roma http://www.fao.org/3/i2000e/ i2000e00.htm. Accessed 22 Nov 2020

FAO (2020a) Evaluación de los recursos forestales mundiales 2020, Roma. https:// doi.org/10.4060/ca8753es

FAO (2020b) Global Forest Resources Assessment 2020: Main report, China's Commercial Health Insurance. Rome. https://doi.org/10.4324/97804293404 06-1

FAO, PNUMA (2020) El estado de los bosques del mundo 2020: Los bosques, la biodiversidad y las personas. Roma.

Feng Y, Chen X, Gao F, Liu Y (2018) Impacts of changing scale on Getis-Ord Gi* hotspots of CPUE: a case study of the neon flying squid (Ommastrephes bartramii) in the Northwest Pacific Ocean. Acta Oceanol Sin 37:67-76. https:// doi.org/10.1007/s13131-018-1212-6

Ferrer-Paris JR, Zager I, Keith DA, Oliveira-Miranda MA, Rodríguez JP, Josse C, González-Gil M, Miller RM, Zambrana-Torrelio C, Barrow E (2018) An ecosystem risk assessment of temperate and tropical forests of the Americas with an outlook on future conservation strategies. Conserv Lett 12(2):e12623. https://doi.org/10.1111/conl.12623

Ford SA, Jepsen MR, Kingston N, Lewis E, Brooks TM, MacSharry B, Mertz O (2020) Deforestation leakage undermines conservation value of tropical and subtropical forest protected areas. Glob Ecol Biogeogr 29(11):2014-2024. https://doi.org/10.1111/geb.13172

Forman RTT, Godron M (1989) Landscape ecology. Wiley, New York

Fuchs EJ, Lobo JA, Quesada M (2003) Effects of forest fragmentation and flowering phenology on the reproductive success and mating patterns of the tropical dry forest tree Pachira quinata. Conserv Biol 17(1):149-157. https://doi.org/10.1046/j.1523-1739.2003.01140.x

Guerrero-Casado J, Seoane JM, Aguirre N, Torres-Porras J (2021) Success in conserving the bird diversity in tropical forests through private protected areas in Western Ecuador. Neotrop Biol Conserv 16(2):351-367. https://doi. org/10.3897/neotropical.16.e63414 
Hargis CD, Bissonette JA, David JL (1998) The behavior of landscape metrics commonly used in the study of habitat fragmentation. Landsc Ecol 13(3): 167-186. https://doi.org/10.1023/A:1007965018633

Hermosilla T, Wulder MA, White JC, Coops NC, Pickell PD, Bolton DK (2018) Impact of time on interpretations of forest fragmentation: three-decades of fragmentation dynamics over Canada. Remote Sens Environ 222:65-77. https://doi.org/10.1016/j.rse.2018.12.027

Hoekstra JM, Boucher TM, Ricketts TH, Roberts C (2005) Confronting a biome crisis: global disparities of habitat loss and protection. Ecol Lett 8(1):23-29. https://doi.org/10.1111/j.1461-0248.2004.00686.x

INEC (2019) Contenido Encuesta de Superficie y Producción Agropecuaria Continua (ESPAC) 2018, Inec.

Instituto nacional de estadística (2019) Contador Nacional de población. http:// www.ecuadorencifras.gob.ec/estadisticas/. Accessed 9 May 2019.

Instituto nacional de estadisticas y censos (2010) Población y Demografía. https:// www.ecuadorencifras.gob.ec/censo-de-poblacion-y-vivienda/. Accessed 22 Nov 2020.

Kupfer JA (2006) National assessments of forest fragmentation in the US. Glob Environ Chang 16(1):73-82. https://doi.org/10.1016/j.gloenvcha.2005.10.003

Laurance WF, Carolina Useche D, Rendeiro J, Kalka M, Bradshaw CJA, Sloan SP, Laurance SG, Campbell M, Abernethy K, Alvarez P, Arroyo-Rodriguez V, Ashton P, Benítez-Malvido J, Blom A, Bobo KS, Cannon CH, Cao M, Carroll R, Chapman C, Coates R, Cords M, Danielsen F, De Dijn B, Dinerstein E, Donnelly MA, Edwards D, Edwards F, Farwig N, Fashing P, Forget PM, Foster M, Gale G, Harris D, Harrison R, Hart J, Karpanty S, John Kress W, Krishnaswamy J, Logsdon W, Lovett J, Magnusson W, Maisels F, Marshall AR, McClearn D, Mudappa D, Nielsen MR, Pearson R, Pitman N, Van Der Ploeg J, Plumptre A, Poulsen J, Quesada M, Rainey H, Robinson D, Roetgers C, Rovero F, Scatena F, Schulze C, Sheil D, Struhsaker T, Terborgh J, Thomas D, Timm R, Nicolas Urbina-Cardona J, Vasudevan K, Joseph Wright S, Carlos Arias-G J, Arroyo L, Ashton M, Auzel P, Babaasa D, Babweteera F, Baker P, Banki O, Bass M, Bila-Isia I, Blake S, Brockelman W, Brokaw N, Brühl CA, Bunyavejchewin S, Chao JT, Chave J, Chellam R, Clark CJ, Clavijo J, Congdon R, Corlett R, Dattaraja HS, Dave C, Davies G, De Mello BB, De Nazaré Paes Da Silva R, Di Fiore A, Diesmos A, Dirzo R, Doran-Sheehy D, Eaton M, Emmons L, Estrada A, Ewango C, Fedigan L, Feer F, Fruth B, Giacalone Willis J, Goodale U, Goodman S, Guix JC, Guthiga P, Haber W, Hamer K, Herbinger I, Hill J, Huang Z, Fang Sun I, Ickes K, Itoh A, Ivanauskas N, Jackes B, Janovec J, Janzen D, Jiangming $M$, Jin C, Jones T, Justiniano $H$, Kalko E, Kasangaki A, Killeen T, King HB, Klop E, Knott C, Koné I, Kudavidanage E, Lahoz Da Silva Ribeiro J, Lattke J, Laval R, Lawton R, Leal M, Leighton M, Lentino M, Leonel C, Lindsell J, LingLing L, Eduard Linsenmair K, Losos E, Lugo A, Lwanga J, MacK AL, Martins M, Scott McGraw W, McNab R, Montag L, Myers Thompson J, Nabe-Nielsen J, Nakagawa M, Nepal S, Norconk M, Novotny V, O'Donnell S, Opiang M, Ouboter P, Parker K, Parthasarathy N, Pisciotta K, Prawiradilaga D, Pringle C, Rajathurai S, Reichard U, Reinartz G, Renton K, Reynolds G, Reynolds V, Riley E, Rödel MO, Rothman J, Round P, Sakai S, Sanaiotti T, Savini T, Schaab G, Seidensticker J, Siaka A, Silman MR, Smith TB, De Almeida SS, Sodhi N, Stanford C, Stewart K, Stokes E, Stoner KE, Sukumar R, Surbeck M, Tobler M, Tscharntke T, Turkalo A, Umapathy G, Van Weerd M, Vega Rivera J, Venkataraman M, Venn L, Verea C, Volkmer De Castilho C, Waltert M, Wang B, Watts D, Weber W, West P, Whitacre D, Whitney K, Wilkie D, Williams S, Wright DD, Wright P, Xiankai L, Yonzon P, Zamzani F (2012) Averting biodiversity collapse in tropical forest protected areas. Nature 489(7415):290 293. https://doi.org/10.1038/nature11318

Laurance WF, Sayer J, Cassman KG (2014) Agricultural expansion and its impacts on tropical nature. Trends Ecol Evol 29(2):107-116. https://doi.org/10.1016/j. tree.2013.12.001

Leautaud Valenzuela P (2014) Fragmentación Forestal de la reserva monarca: cuantificación, caracterización, y correlaciones (1990-2010). Universidad nacional autónoma de México

Lessmann J, Muñoz J, Bonaccorso E (2014) Maximizing species conservation in continental Ecuador: a case of systematic conservation planning for biodiverse regions. Ecol Evol 4(12):2410-2422. https://doi.org/10.1002/ece3.11 02

Loaiza S (2013) The Tumbesian center of endemism: biogeography, diversity and conservation. Biogeografía 6:4-10

MAE, MAGAP (2015) Protocolo metodológico para la elaboración del mapa de cobertura y uso de la tierra del Ecuador Continental 2013-2014 escala 1:100. 000. Ministerio del Ambiente del Ecuador y Ministerio de Agricultura, Ganadería, Acuacultura y Pesca
Manchego CE, Hildebrandt P, Cueva J, Espinosa Cl, Stimm B, Günter S (2018) Climate change versus deforestation: implications for tree species distribution in the dry forests of southern Ecuador. PLoS One 13(4):e0195851. https://doi.org/10.1371/journal.pone.0195851

Margules CR, Pressey RL (2000) Systematic conservation planning. Nature 405(6783):243-253. https://doi.org/10.1038/35012251

McGarigal K, Marks BJ (1995) FRAGSTATS: spatial pattern analysis program for quantifying landscape structure. Gen tech rep PNW-GTR-351. U.S. Department of Agriculture, Forest Service, Pacific Northwest Research Station, Portland

Ministerio del Ambiente (2012) Línea base de deforestación del ecuador continental. Quito: Ministerio del Ambiente

Ministerio del Ambiente (2017) Deforestación del Ecuador Continental Periodo 2014-2016. http://reddecuador.ambiente.gob.ec/redd/wp-content/uploads/2 019/12/Anexo-5.-Informe-de-Deforestaci\%C3\%B3n-Ecuador-Continentalperiodo-2014-2016.pdf. Accessed 22 Nov 2020.

Ministerio del ambiente de Ecuador (2015) Fragmentacion De Ecosistemas Del Ecuador Contimental. Subsecretaria de Patrimonio Natural, Quito

Ministerio del ambiente del Ecuador (2012) Especies forestales de los bosques secos del Ecuador. Bosques Secos en Ecuador y su diversidad, Quito

Ministerio del ambiente del Ecuador (2013) Sistema de Clasificación de los Ecosistemas del Ecuador Continental. Subsecretaría de Patrimonio Natural, Subsecretaría de Patrimonio Natural, Quito

Nelson HP, Devenish-Nelson ES, Rusk BL, Geary M, Lawrence AJ (2020) A review of tropical dry forest ecosystem service research in the Caribbean - gaps and policy-implications. Ecosyst Serv 43:101095. https://doi.org/10.1016/j.ecoser.2 020.101095

Ord JK, Getis A (1995) Local spatial autocorrelation statistics: distributional issues and an application. Geogr Anal 27(4):286-306. https://doi.org/10.1111/j.153 8-4632.1995.tb00912.x

Parr TW, Jongman RHG, Külvik M (2010) The selection of biodiversity indicators for EBONE development work. EBONE European Biodiversity Observation Network: Design of a plan for an integrated biodiversity observing system in space and time, European Biodiversity Observation Network

Peralvo M, Delgado J (2010) Metodología para la Generación del Mapa de Deforestación Histórica. Quito: Ministerio del Ambiente and CONDESAN

Portillo-Quintero CA, Sánchez-Azofeifa GA (2010) Extent and conservation of tropical dry forests in the Americas. Biol Conserv 143(1):144-155. https://doi. org/10.1016/j.biocon.2009.09.020

Prentice KC (1990) Bioclimatic distribution of vegetation for general circulation model studies. J Geophys Res 95(D8):11.811-11.830. https://doi.org/10.1029/ jd095id08p11811

Prieto-Torres DA, Nori J, Rojas-Soto OR (2018) Identifying priority conservation areas for birds associated to endangered Neotropical dry forests. Biol Conserv 228:205-214. https://doi.org/10.1016/j.biocon.2018.10.025

Puyravaud J-P (2003) Standardizing the calculation of the annual rate of deforestation. For Ecol Manag 177(1-3):593-596. https://doi.org/10.1016/S03 78-1127(02)00335-3

Rempel RS, Kaukinen D, Carr A (2012) Patch analyst and patch grid. Ontario Ministry of Natural Resources, Centre for Northern Forest Ecosystem Research, Thunder Bay

Rivas CA, Navarro-Cerillo RM, Johnston JC, Guerrero-Casado J (2020) Dry forest is more threatened but less protected than evergreen forest in Ecuador's coastal region. Environ Conserv 47(2):79-83. https://doi.org/10.1017/S03 76892920000077

Rios E, Benchimol M, Dodonov P, et al (2021) Testing the habitat amount hypothesis and fragmentation effects for medium- and large-sized mammals in a biodiversity hotspot. Landsc Ecol 36:1311-1323. https://doi.org/10.1007/ s10980-021-01231-9

Sales LP, Galetti M, Pires MM (2020) Climate and land-use change will lead to a faunal "savannization" on tropical rainforests. Glob Chang Biol 26(12):70367044. https://doi.org/10.1111/gcb.15374

Sandoval MFL, Gerique A, Pohle P (2017) What is behind land claims? Downsizing of a conservation area in southeastern Ecuador. Sustainability 9(9):1-15. https://doi.org/10.3390/su9091519

Sierra R (2013) Patrones y factores de deforestación en el ecuador continental, 1990-2010. Y un acercamiento a los próximos 10 años. Conservación Internacional Ecuador y Forest Trends, Quito

Sierra R, Campos F, Chamberlin J (2002) Assessing biodiversity conservation priorities: Ecosystem risk and representativeness in continental Ecuador. Landsc Urban Plan 59:95-110. https://doi.org/10.1016/S0169-2046(02)00006-3 
Siyum ZG (2020) Tropical dry forest dynamics in the context of climate change: syntheses of drivers, gaps, and management perspectives. Ecol Process 9(1): 25. https://doi.org/10.1186/s13717-020-00229-6

Smith V, Portillo-Quintero C, Sanchez-Azofeifa A, Hernandez-Stefanoni JL (2019) Assessing the accuracy of detected breaks in Landsat time series as predictors of small scale deforestation in tropical dry forests of Mexico and Costa Rica. Remote Sens Environ 221:707-721. https://doi.org/10.1016/j.rse.2 018.12.020

Solórzano CB, Intriago-Alcívar L, Guerrero-Casado J (2021) Comparison between terrestrial mammals in evergreen forests and in seasonal dry forests in Western Ecuador: should efforts be focused on dry forests? Mammalia. 0(0). https://doi.org/10.1515/mammalia-2020-0145

Tapia-Armijos MF, Homeier J, Espinosa Cl, Leuschner C, De La Cruz M (2015) Deforestation and forest fragmentation in South Ecuador since the 1970s losing a hotspot of biodiversity. PLoS One 10(9):e0133701. https://doi.org/1 0.1371/journal.pone.0133701

Taubert F, Fischer R, Groeneveld J, Lehmann S, Müller MS, Rödig E, Wiegand T, Huth A (2018) Global patterns of tropical forest fragmentation. Nature 554(7693):519-522. https://doi.org/10.1038/nature25508

Trejo I, Dirzo R (2000) Deforestation of seasonally dry tropical forest: a national and local analysis in Mexico. Biol Conserv 94(2):133-142. https://doi.org/10.1 016/S0006-3207(99)00188-3

Trigueiro WR, Nabout JC, Tessarolo G (2020) Uncovering the spatial variability of recent deforestation drivers in the Brazilian Cerrado. J Environ Manag 275: 111243. https://doi.org/10.1016/j.jenvman.2020.111243

Tulloch AIT, Barnes MD, Ringma J, Fuller RA, Watson JEM (2016) Understanding the importance of small patches of habitat for conservation. J Appl Ecol 53(2):418-429. https://doi.org/10.1111/1365-2664.12547

van Der Hoek Y (2017) The potential of protected areas to halt deforestation in Ecuador. Environ Conserv 44(2):124-130. https://doi.org/10.1017/S03768929 $700011 X$

Villacís B, Carrillo D (2012) Estadística Demográfica en el Ecuador: Diagnóstico y Propuesta. Instituto Nacional de Estadística y Censos (INEC), Quito

Volenec ZM, Dobson AP (2020) Conservation value of small reserves. Conserv Biol 34(1):66-79. https://doi.org/10.1111/cobi.13308

Whelan CJ, Maina GG (2005) Effects of season, understorey vegetation density, habitat edge and tree diameter on patch-use by bark-foraging birds. Funct Ecol 19(3):529-536. https://doi.org/10.1111/j.1365-2435.2005.00996.x

\section{Submit your manuscript to a SpringerOpen ${ }^{\circ}$ journal and benefit from:}

- Convenient online submission

- Rigorous peer review

- Open access: articles freely available online

- High visibility within the field

- Retaining the copyright to your article

Submit your next manuscript at $\boldsymbol{\nabla}$ springeropen.com 